\title{
A intersecção entre o imaginário do fascismo, do império e da política colonial em Paisagem com mulher e mar ao fundo de Teolinda Gersão
}

\author{
The intersection between the imaginary of Fascism, Empire and Colonial Politics in \\ Paisagem com mulher e mar ao fundo by Teolinda Gersão
}

José N. Ornelas

University of Massachusetts Amherst - Amherst - Massachusetts - EUA

$\diamond$

\begin{abstract}
Resumo: O presente ensaio é um reflexão sobre a construção no romance Paisagem com mulher e mar ao fundo de Teolinda Gersão do imaginário político, social e cultural português durante o período do regime fascista de Oliveira Salazar e a forma como ele justifica e serve de suporte ideológico à retórica imperialista/colonialista de Portugal. O ensaio também demonstra como o ditador O.S. (codificação de Oliveira Salazar) usa o poder coercivo de uma linguagem que se fundamenta em mitos, símbolos, cerimónias, exposições e rituais para controlar, silenciar e reprimir o povo português e paralisar a nação. Finalmente, analisa-se a desmitificação e a subversão do poder tirânico que o líder politico exerce no seu reino, o mar, símbolo de morte e de estagnação, e a substituição do reino do mar pelo da terra, símbolo de vida e de criatividade.

Palavras-chave: fascismo, império, mito, mar/terra, imaginário
\end{abstract}

\begin{abstract}
This essay is a reflection on the construction in the novel Paisagem com mulher e mar ao fundo by Teolinda Gersão of the Portuguese political, social and cultural imaginary and the ways by which it serves as ideological support for the imperialist/colonialist rhetoric of Portugal. The essay also demonstrates how the dictator O.S. (codification of Oliveira Salazar) uses the coercive power of a language that is founded on myths, symbols, ceremonies, expositions and rituals to control, silence and repress the Portuguese people and to paralyze the nation. Finally, we analyze the demystification and the subversion of the tyrannical power that the political leader wields in his kingdom, the sea, and the substitution of the kingdom of the sea by that of the land, symbol of life and creativity.
\end{abstract}

Keywords: Fascism, empire, myth, sea/land, imaginary

O Boletim da Agência Geral das Colónias, órgão oficial da acção colonial portuguesa, propõe-se fazer a propaganda do nosso património colonial, contribuindo por todos os meios para o seu engrandecimento, defesa, estudo das suas riquezas e demonstração das aptidões e capacidade colonizadora dos portugueses.

(Boletim da Agência Geral das Colónias) ${ }^{1}$

... o Senhor do Mar é o Senhor da Morte e a sua ambição não tem limite, porque nos aniquilamos ele impera e porque desistimos de viver ele se apodera da nossa força...

(Teolinda Gersão) $)^{2}$

AGÊNCIA GERAL DAS COLÓNIAS. Boletim Geral das Colónias. Lisboa, v. 1, p. 230, 1925.

2 Paisagem com mulher e mar ao fundo. Lisboa: O Jornal, 1982. p. 113. 
Dada a índole ideológica deste ensaio, é apropriado que as duas epígrafes que o encimam se relacionem com o imaginário do império e do regime salazarista, um imaginário formado e informado por cerimónias, imagens, exposições, metáforas, mitos e rituais cuja função ideológica primária era paralisar, aniquilar e silenciar o povo português, como sugere Teolinda Gersão via a sua referência na segunda epígrafe ao Senhor do Mar/Senhor da Morte (com maiúsculas), símbolo do poder e da tirania. A primeira epígrafe, ao contrário da segunda que denuncia a fantasmagoria imperial que emascula a nação, enaltece e glorifica o passado colonizador português. Também afirma o valor da participação de múltiplos órgãos oficiais na propaganda do património colonial da nação por ser um direito que os portugueses conquistaram através da sua dedicação à missão civilizadora e do muito que se sacrificaram para levá-la a cabo nas alegadas terras viciosas camonianas. A propaganda é uma espécie de homenagem a Portugal e ao papel que o país desempenhou em uma colonização desinteressada de outros povos, segundo a retórica oficial colonialista. Como bem observa o próprio Salazar, o artífice do Estado Novo e ditador de Portugal por um período de quase quarenta anos, "um povo pode criar em seu seio princípios norteadores de acção universal, irradiar fachos de luz que iluminem o mundo" (Boletim Geral das Colónias, v. 17, n. 167, p. 26, 1949) e pode ter "oito séculos de independência, de vida livre e de trabalho intenso, em grande parte desinteressado e a favor dos outros povos da terra" (Boletim Geral das Colónias, v. 17, n. 167 , p. 7,1949 ) O discurso imperial português perpetuou-se por vários séculos através de uma roupagem retórica grandiloquente, hiperbólica e pomposa, ausente de conteúdo, que continuamente reafirmou e justificou a grandeza e o valor sacralizado da missão civilizadora, uma missão que permaneceu como um dos grandes projectos políticos do regime fascista até 1974 , ano da Revolução dos Cravos, e que Margarida Calafate Ribeiro e Ana Paula Ferreira designam como uma das muitas "ficções de uma nação em busca de universalidade" (9).

Teolinda Gersão, a autora da segunda epígrafe deste texto, é uma das vozes mais importantes e inovadoras da narrativa portuguesa contemporânea. Algumas das suas obras, nomeadamente os romances Paisagem com mulher e mar ao fundo (1982) ${ }^{3}$ e A árvore das palavras (1997), insurgem-se contra as múltiplas ficções e figurações do império e do Estado Novo referidas no primeiro parágrafo deste ensaio. Com uma obra vasta de alta qualidade artística e sumamente imaginativa, rica, plurivocal e diferenciada em termos da forma singular como a autora representa o contexto social, político, histórico, cultural, ideológico e humano nos seus textos, pode-se afirmar que Teolinda Gersão é uma figura que já ocupa uma posição de proeminência no cânone literário português actual. Algumas das sua obras já foram traduzidas a vários idiomas, facto que não só comprova o estatuto e valor da escritora no panorama pós-revolucionário e pós-colonial português actual mas também lhe dá uma dimensão mais global.

Entre as muitas ficções, mitos, rituais e símbolos contra os quais se insurge a obra de Teolinda Gersão, devemos destacar os que se seguem: a responsabilidade, os serviços e os sacrifícios pela causa da missão civilizacional; a busca da universalidade; a vocação marítima; a glória e o orgulho do passado grandioso; a dilatação do império espiritual cristão; o idealismo da expansão; a suposta unidade inter-racial e pluricontinental da nação/império adaptada das teorias lusotropicalistas de Gilberto Freyre; a vocação colonizadora e imperialista; a galeria de antepassados ilustres alguns dos quais no imaginário de Paisagem, o romance a ser analisado neste ensaio, se convertem em deuses da morte ou deuses do mar como O.S. (codificação de Oliveira Salazar), figura mítica que não representa um aspecto modelar da nação e do império português celebrado pela retórica fascista mas sim a tirania e uma ideologia estagnadora, castradora e repressiva, de acordo com a sua representação textual. ${ }^{4}$

A narrativa de Paisagem destaca sobretudo os temas fulcrais relacionados com o período fascista e prérevolucionário português, ou seja, a época associada com o Estado Novo e o ditador Oliveira Salazar: a construção do poder; a resistência e o desafio ao poder do regime; a produção da iconografia e da retórica fascista; a assimetria das relações sociais e de género; a configuração do corpo; a linguagem como mecanismo de controle, de repressão, do silenciamento e até de total aniquilamento do indivíduo; a ilustração do poder hegemónico fascista, patriarcal e hiper-masculino; a relação da nação com o mar e este com a identidade nacional; e, finalmente, a Revolução do 25 de Abril. A Revolução dos Cravos é mais um acto simbólico e, em grande medida, enigmático e implícito do que um evento real no texto. De facto, não há nenhuma referência à Revolução de 1974 nem à palavra revolução na narrativa. $\mathrm{O}$ texto unicamente refere-se a um milagre, ou à festa da vida, ou a uma festa que se altera porque o que acontece durante a celebração não era o previsível. No episódio em questão, o povo participa em uma cerimónia para celebrar o Deus do Mar/Deus da Morte, à qual o narrador se refere como festa da morte.

\footnotetext{
3 De agora em diante, vamos referir-nos ao romance como Paisagem.

4 Em um artigo anterior, "Paisagem com mulher e mar ao fundo: a positividade e a afirmação da diferença," publicado em $O$ despertar de $E v a$ : gênero e identidade na ficção de língua portuguesa já tínhamos analisado vários aspectos do romance enfocando-nos sobretudo no papel de Hortense na luta contra o poder de O.S. Neste ensaio, a nossa intenção fundamental é demonstrar a forma como a retórica fascista/imperialista controla e subjuga todos os portugueses e imobiliza a nação.
} 
Depois de um longo percurso de caminho e de duração da cerimónia, de repente, em uma espécie de ruptura ou transmutação do real, ou seja, do previsível, a cerimónia transforma-se em celebração da vida acompanhada por uma concomitante destruição da imagem do Deus do Mar/Deus da Morte, quando a imagem cai do andor e é destroçada contra as falésias. Incidente análogo sucedeu a Salazar em 1968 quando o ditador caiu do seu trono, a cadeira, segundo uma das várias teses sobre o incidente. A queda supostamente causou-lhe uma trombose cerebral, a razão da sua morte dois anos depois.

De acordo com o romance, no preciso momento que cai o Deus do Mar sobre as falésias, as pessoas do povo

[...] deitam ao chão os festões e as luzes e arrancam as rosas de papel, o andor quebrou-se ao meio e o pálio está rasgado, era a festa da morte, gritam, mas doravante é a festa da vida, ele caiu do seu trono e somos nós agora os senhores do mar e os senhores da terra, desvendámos o enigma e encontrámos a saída do seu reino, não partiremos porque esta terra é nossa [...] ele não tinha limite, e por isso o derrubámos, e doravante faremos nós a lei (114).

Celebra-se o milagre, a voz do alti-falante muda, a música muda e doravante "encontro a minha voz [povo], o meu corpo, as minhas mãos o meu grito o meu ódio, e pelo menos isso, pelo menos isso me pertence, o direito de enfrentar-te [O.S.] e de medir contigo a minha força" (p. 113-114). Finalmente, o povo aniquila o Deus do Mar, ou seja, o próprio mar, símbolo e causa directa da morte da nação, "um povo de afogados, sem revolta" (109), um povo, portanto, que se caracteriza, conforme a perspectiva do mar, por sua cumplicidade activa com o poder e que implicitamente aceita os indivíduos que exercem esse poder. O mar com a sua voz e o seu poder sempre havia silenciado o povo ou a nação, havia obrigado o povo a render-se ao seu poder e havia-o adormecido nas suas águas. $\mathrm{O}$ mar foi um elemento com uma força mítica avassaladora e violenta na expansão portuguesa pelo mundo, dada a sua intersecção com a missão civilizadora, a construção do império, a luta armada nas colónias, a suposta vocação marítima dos portugueses e as "aptidões e capacidade colonizadora dos portugueses" (Boletim da Agência Geral das Colónias, v. 1, n. 2, p. 230). O mar tinha sido, por séculos, a mais significativa âncora e arma ideológica do país e a sua razão de ser. E o mar tinha tido muitos cúmplices no seu reino de terror.

Com a queda do Senhor do Mar/Senhor da Morte, reduzido agora a um monte de destroços nas falésias, a sacralização da imagem converte-se em uma dessacralização ou profanação da imagem e do poder institucionalizado representado como um culto religioso em Paisagem, ligado duplamente à morte e ao mar. Maria
Heloísa Martins Dias salienta que é com a profanação da imagem do mar "que se dá o desvendamento de uma verdade há séculos ocultada pela figura mítica do mar: a terra pertence ao povo, que não precisa partir mais, basta inverter a rota do seu destino em relação ao que lhe fora imposto. A obediência aos rituais - o caminhar lento, o culto apaixonado da imagem, a peregrinação mecânica e passiva - cede lugar à ruptura" (1) com o passado e o carácter identitário da nação, assim como todos os mitos, símbolos, rituais e metáforas que alicerçaram Portugal. A inversão e negação do verso camoniano "onde a terra se acaba e o mar começa" por "[aqui] onde o mar acaba e a terra principia" ( $O$ ano da morte de Ricardo Reis, 1987, p. 11) que, por coincidência, é a primeira oração do romance de José Saramago ou outra oração análoga de Paisagem, "[v]oltar as costas ao mar e encontrar a terra" (61), devem ser o novo lema da nação e tem que ser o futuro caminho a trilhar. Ao contrário do que diz Fernando Pessoa, [n] avegar é preciso", o que sustenta tanto o texto de José Saramago como o de Teolinda Gersão é um nova concepção da realidade que tem em conta e se fundamenta na contingência histórica do país para anular a força do mar mítico: caminhar é preciso. De facto, caminhar é preciso para conhecer e descobrir a terra incógnita e, através do próprio acto de caminhar, criar um novo imaginário que reflecte a nova realidade póscolonial, visto que as aventuras além-mar, transformadas em mitos através dos tempos, sempre desviaram o povo português do verdadeiro conhecimento e da descoberta da terra portuguesa, a qual ainda continua viciosa, conforme os dois escritores.

Paisagem representa Portugal como terra incógnita porque o capital simbólico e real do mar, ou seja, a mitologia do império e também do Estado Novo, tem incessantemente transformado os objectos da história em categorias fixas ou imutáveis. Em um país prisioneiro da mitologia/retórica do império, caso de Portugal, o mito actua de forma económica, segundo Roland Barthes, em Mythologies visto que

it abolishes the complexity of human acts, it gives them the simplicity of essences, it does away with all dialectics, it organizes a world which is without contradictions because it is without depth, a world wide open and wallowing in the evident, it establishes a blissful clarity: things appear to mean something by themselves (BARTHES, 1976, p. 143).

O objectivo fundamental em um país alicerçado na mitologia do império ou do fascismo é a preservação de uma imagem esvaziada de sua contingência história e não a transformação da realidade ou do mundo. Portanto, Paisagem recorre continuamente ao uso do mito, visto que este se define não por seu sentido literal mas pela sua 
intenção, uma intenção congelada e congeminada como se fosse eterna. $\mathrm{O}$ texto descreve um mundo imobilizado e paralisado que recorre a uma metalinguagem, uma linguagem de segunda ordem relacionada com a celebração do mundo, ou seja, uma linguagem que tem como seu objectivo essencial valorizar e naturalizar a ideologia e os valores hegemónicos que sempre se projectam como sacralizados, absolutos e perenes. A metalinguagem pertence exclusivamente ao opressor, neste caso, à ordem fascista e imperialista que impera no país. Um dos objectivos fundamentais da ordem dominante é conservar a realidade; não é fazê-la ou actuar sobre ela. $\mathrm{O}$ fazer ou o actuar sobre a realidade significa a sua transformação que, por seu turno, é um acto político relacionado com "the whole of human relations in their real, social structure, in their power of making the world" (BARTHES, 1976, p. 143) e, por conseguinte, não faz parte da estrutura do mito visto que este defrauda e priva a linguagem da sua contingência histórica.

A linguagem do mito é sempre plenária, cerimonial, ritual, gestual e teatral, facto bem evidenciado em muitos episódios de Paisagem, especialmente os associados a Áurea, professora de escola primária, os quais continuamente intersectam com a retórica fascista/ imperialista pelo seu apoio incondicional a ela e à figura suprema desse discurso, O.S., personagem invisível e ausente da narrativa mas simbolicamente omnipresente e omnipotente, que ela considera uma espécie de Deus/ Cristo/anjo/mito, dado que ele é a segurança e a força do povo, uma figura sentada "numa cadeira de ouro e [de onde] não sai nunca porque todos os lugares do mundo estão nele, ele é o alfa e o ómega, o princípio e o fim" (83). De acordo com Áurea, da figura invisível e ausente de O.S., brota não só todo o poder real e o capital simbólico de Portugal mas também de todo o mundo. Dado o facto de que todos os lugares do mundo estão em O.S. porque ele os controla, o texto parece afirmar que o poder não existe fora dele; ele é o paradigma do poder. Desta afirmação pode-se deduzir também que fora do discurso de O.S. não há qualquer espaço a partir do qual uma oposição possa ser engendrada.

Além do mais, o poder real ou simbólico, segundo Áurea, reside exclusivamente na figura masculina: Deus ou O.S. ou o homem porque o Senhor (Deus) é o princípio e o fim. O poder codificado como masculino é para ela uma verdade absoluta e inquestionável. O poder desejase "forte, sereno, másculo" (88). Um dos objectivos principais de Áurea na sua vida, como também o devia ser para todas as mulheres, é manter a ordem dominante preservando, no processo, as relações de poder existentes entre homens e mulheres. Segundo ela, a ordem natural do mundo fundamenta-se em certos princípios básicos incontestáveis e invioláveis: os interesses da mulher têm que ser sempre subordinados aos interesses do homem e o papel normal e natural da mulher é servir o homem, ter acesso mais limitado ao conhecimento, aceitar as estruturas patriarcais como naturais e não ter a mínima noção de que o género é construído social e culturalmente e que muda historicamente. Áurea sublinha que agora

\begin{abstract}
as mulheres querem saber tanto como os homens, ser tanto como os homens, [...] elas competiam com eles, queriam roubar o seu lugar no mundo, as mães abandonavam os filhos, [...] as mães tomavam contraceptivos para terem amantes livremente - a sabotagem à própria natureza, a desobediência à lei de Deus e da Igreja - até isso, oh Deus, até isso elas faziam, - a culpa do descalabro e do mal era toda das mulheres, das mães (86-87).
\end{abstract}

Na perspectiva de Áurea, o homem, ou melhor O.S., é o princípio organizador da realidade por todos os lugares do mundo estarem nele; é ele o detentor da linguagem através da qual se exerce o poder. Ela aceita sem qualquer questionamento a sua posição de objecto do discurso tradicional/masculino/fascista. Ela nunca se vê como sujeito do discurso porque essa posição é exclusiva ao homem. Ela é, em grande medida, cúmplice da sua posição porque participa activamente na sua própria sujeição, como muitos outros indivíduos em situações idênticas. Ela e estes

\section{recognize and tacitly acknowledge the legitimacy of power, or the hierarchical relations of power in which they are embedded; and hence they fail to see that the hierarchy is, after all, an arbitrary social construction which serves the interests of some groups more than others (BORDIEU, 1991, p. 23).}

O seu único interesse na vida, para além do seu apoio incondicional a O.S. e à retórica fascista, é reproduzir formas de discurso que a ancoram de maneira firme dentro da retórica tradicional do patriarcado, do discurso masculinista, facto que a leva a uma repressão constante do corpo e do desejo sexual por os dois serem excesso no que concerne a normatividade patriarcal. $\mathrm{O}$ policiamento e a vigilância do seu corpo, a negação ou renúncia do corpo, manter total controle sobre si mesma, ou seja, "dominar o corpo com os grilhões do espírito" (89) e a sua relação mística com O.S. possuem fortes rasgos masoquistas que são fonte de prazer para ela, embora ela sempre negue qualquer prazer masoquista. De facto, a única intenção das suas acções é "corrigir a natureza" (89). Devido à força da natureza sobre o indivíduo, ela considera que certas palavras por serem puras tentações não devem fazer parte do código linguístico. Somente o pensar "sem querer em pecado subversão ou sujidade" (87) causa-lhe uma perda instantânea de controle 
sobre o seu corpo embora ela mencione hipocritamente no texto que "era desligada do corpo, como se não fosse de carne mas de outra matéria mais sublime" (88).

Outros episódios associados a Áurea, como os das composições e dos exercícios repetitivos dos seus alunos, a escritura da mesma oração múltiplas vezes, os quais têm uma intenção e função ideológica fascista/imperialista, visto que não só repetem os lugares comuns da retórica do império e do Estado Novo mas também desempenham um papel estagnador e opressivo: "[c]orrigir a natureza, substitui-la por outra, adquirida e mais perfeita. Não deixar as crianças sentir nem pensar livremente, mas ensinar-lhes o que sentir e pensar" (89). Na perspectiva de Áurea, educar é reprimir. Portanto, a sua missão no mundo coincide com a do regime fascista/colonialista. Até no seu nome, Áurea relaciona-se com o regime fascista porque o seu nome é um símbolo/alusão às épocas áureas de Portugal nas quais se fundamenta a ideologia fascista/imperialista. Como representante e militante dos ideais, valores e atitudes desse passado glorioso, a única missão de Áurea na vida e todos os seus esforços têm como único objectivo a divulgação e a propagação dos ideais tradicionais do passado, assim como da noção de uma nação organizada, hierarquizada, una e indivisa em que todos os cidadãos, por obrigação, devem seguir uma vida extremamente normatizada e controlada. Para levar a cabo e à perfeição o papel honrado e desinteressado que lhe compete como militante e fanática do regime, um papel que ela abraça como a mais alta vocação social, Áurea mantém que os alunos têm de reger-se por determinadas pautas e regras. Ela é da firme convicção que todas as frases das composições e dos exercícios escolares devem começar de forma idêntica, norma que as crianças internalizam rapidamente e que vem

espontaneamente à superfície. Devemos. Redacção a pátria, redacção a família, redacção Deus, devemos amar a pátria, respeitar a família, adorar a Deus, devemos dar a vida pela pátria, honrar a família, respeitar a Deus, devemos deixar tudo para seguir a Deus, dar a vida pela família e sacrificar-nos pela pátria. Um dia seria tudo natural, automático, as ideias viriam por si mesmas e pareceriam irrefutáveis, mesmo quando ela não estivesse mais lá, para apontar a direcção e o caminho.

Deixaria bem fundo a sua marca, pensou olhando a classe, inebriando-se com a vertigem de poder que a assaltou de repente (90).

Este excerto de Paisagem exemplifica perfeitamente o modo como a doutrina e a ideologia imperialista/fascista funciona: a repetição de frases e palavras, como dever, honrar, sacrificar, respeitar, dar a vida, honrar, adorar, todas elas associadas, de alguma forma, com as três palavras-chave da tríade grandiosa da retórica fascista, a Trilogia Nacional: Deus, pátria e família. Facilmente, pode-se inferir do trecho que o método pedagógico de Áurea se caracteriza por uma fé cega em uma ideologia específica e uma ausência total de pensamento crítico em relação a ela. De facto, o seu método promove e garante a submissão total dos alunos à visão do regime fascista, desempenhando, assim, uma forma de regulação social e ideológica que serve unicamente os interesses do Estado-Nação. Além do mais, a repetição das palavras e, consequentemente, das mesmas ideias é uma espécie de lavagem cerebral que não só promove a ideologia fascista mas também faz com que as crianças fiquem, supostamente, com as palavras certas gravadas na memória sem a possibilidade de apagá-las, as quais livram as crianças das palavras falsas em momentos propícios. Acresce que a ideia de espontaneidade a que Áurea alude no trecho é também uma distorção do verdadeiro significado da palavra. Não há nada de espontâneo na resposta ou reacção das crianças. Ao contrário, é uma resposta ou reacção mecânica, programatizada e automática que impossibilita a criança de pensar por si mesma. Por último, a noção de que o uso das palavras e das ideias que as crianças aprendem com Áurea "viriam por si mesmas..., mesmo quando ela não estivesse mais lá, para apontar a direcção e o caminho" (90) sublinha o papel fundamental das palavras na produção do poder simbólico, ideológico e social. De facto, o que afirma Pierre Bourdieu sobre o campo político também explica o que transcorre no campo educacional porque Áurea como professora também é agente político: o campo político é

the site par excellence in which agents seek to form and transform their visions of the world and thereby the word itself: it is the site par excellence in which words are actions and the symbolic character of power is at stake. Through the production of slogans, programmes and commentaries of various kinds, agents are continuously engaged in a labour of representation by which they seek to construct and impose a particular vision of the social world, while at the same time seeking to mobilize the support of those upon whom their power ultimately depends (BORDIEU, 1991, p. 26).

Como propaganda da ordem dominante e de seu chefe supremo, as palavras e orações que os alunos são obrigados a escrever repetidamente partilham das mesmas características que o mito, visto que aquelas como o mito distorcem e falsificam o mundo. Como afirma Roland Barthes, "[t]he relation which unites the concept of the myth to its meaning is essentially a relation of deformation" (BARTHES, 1976, p. 122). Por esta razão, é que os mitos servem modelarmente os desígnios 
ideológicos de sistemas fascistas/imperiais porque eles deformam e privam a relação que o mito tem com o seu significado, ou seja, a sua contingência histórica específica. Ao privar o mito de esta contingência, o mito torna-se extremamente efectivo no controle, repressão e perda de voz do povo, como é o caso em Paisagem.

O próprio texto alude a esta privação que dá outra dimensão à linguagem porque a converte em metalinguagem, ou melhor, não-linguagem ou sua ausência:

Tinha havido tempo em que as palavras eram as casas das coisas, e quando se transpunha a porta as coisas estavam lá, sossegadas e familiares, guardadas e disponíveis prontas para usar de novo. Mas agora as coisas tinham partido de dentro das palavras, e quando ela [Hortense, a protagonista do romance] empurrava a sua porta as palavras eram casas vazias, e ela não saberia mais o lugar de coisa alguma. A terra era um espaço deserto e silencioso, de onde todas as coisas se tinham ausentado (15).

Poder-se-ia afirmar que a mudança da relação das palavras com as coisas - de palavras/signos que representam ou denotam objectos/coisas à ausência e vazamento dos objectos/coisas que os signos/palavras simbolizam - corresponde ao processo da construção do mito. Desafortunadamente, o processo que termina na ausência de uma linguagem/objecto produz uma cisão entre a linguagem e o objecto: as pessoas não podem construir o real ou o mundo com a palavra porque esta perdeu o seu referente histórico - as casas estão vazias. A incapacidade para simbolizar o real devido à ausência das palavras deve-se ao facto de que o regime totalitário fascista tinha-se levantado

acima de todas as coisas, fazendo parar o país, parar o tempo, retroceder séculos atrás, a sua mão parava o vento da mudança e espalhava a areia negra do medo, apertava em torno das casas a mordaça do silêncio, a sua mão castradora retirava ao povo a força da revolta (66).

O cerco apertado ao povo pelo aparato ideológico fascista, literal e figurativamente, deixa pelo caminho os signos visuais da violência: uma procissão de corpos, condenados ao silêncio, exibindo as marcas do poder de O.S. Torna-se quase impossível travar a retórica imobilizadora e castradora do Estado Novo que continuamente invoca e refugia-se em toda uma série de ficções, nomeadamente, a vocação ou carácter universalista da nação aliada, como sempre, a uma missão civilizadora, já notável nas épocas áureas, especialmente na época dos descobrimentos, uma missão que tem a sua justificação no suposto destino místico e cristão da nação (civilizar é preciso porque serve os desígnios de Deus no mundo e expande a fé cristã) e a sua concretização material na vocação imperialista portuguesa que legitima a política colonial portuguesa. Tudo isto se relaciona, de uma maneira ou outra, com uma identidade nacional promovida pelo Estado Novo, o qual não só recorre a ficções mas também a mitos no seu afã por regenerar o país decadente e moral, económica e politicamente moribundo. De facto, na concepção do universalismo da nação/império e tudo o que ela implica em termos de ideologia, identidade nacional e essência do povo português, nota-se a presença do poder do mito, tão bem definido por Fernando Pessoa, no poema Ulisses de Mensagem: "O mito é o nada que é tudo" (PESSOA, 1967, p. 19).

O que é o mito senão roubar a linguagem e apagarlhe a sua memória histórica, a sua correspondência com as coisas, e (re)conceptualizá-la de outra forma, ou seja, dar-lhe "an historical intention, a natural justification, and making contingency appear eternal" (PESSOA, 1976, p. 142), ou seja, fazer do nada tudo, para que, de este modo, o produto final, o mito, possa servir de justificação e garante da retórica imperialista/fascista. A mensagem ideológica do Estado Novo é que a essência da nação sempre foi assim e, portanto, é imutável e fixa. Conforme Barthes,

[t]he world enters language as a dialectical relation between activities, between human actions; it comes out of myth as a harmonious display of essences. A conjuring trick has taken place; it has turned reality inside out, it has emptied it of history and has filled it with nature, it has removed from things their human meaning so as to make them signify a human insignificance. The function of myth is to empty reality: it is, literally, a ceaseless flowing out, a hemorrhage, or perhaps an evaporation, in short a perceptible absence (BARTHES, 1976, p. 142-143).

Assim se actualiza a presença do mito ou mitos, mediante uma suposta despolitização da linguagem e a perda da sua memória histórica porque as palavras já não correspondem a coisas, como sustentam Barthes e Paisagem. A evolução ou transformação de uma linguagem primária a uma linguagem de segunda ordem serve à perfeição as distorções, as falsidades, as manipulações e as tendências maquiavélicas da ideologia fascista/ imperialista. O esvaziar da carga ideológica da linguagem através da sua conversão em mito outorga ironicamente à linguagem um peso ideológico maior, dada a capacidade do mito para ocultar a sua intenção ideológica. Como consequência do processo de vazamento e da perda da memória histórica levado a cabo sobre a linguagem na construção do mito, este obtém ironicamente um poder excessivo para imobilizar e controlar o mundo, facto bem 
comprovado em vários episódios e acções de Paisagem. Já o poeta Fernando Pessoa, de maneira análoga, havia afirmado o mesmo no poema "Ulisses": "Este [Ulisses] que aqui aportou,/ Foi por não ser existindo./ Sem existir nos bastou./ Por não ter vindo foi vindo/ E nos criou" (PESSOA, 1967, p. 25). O mito entra na realidade e fecunda-a; facilita a construção e a visão da nação e, com a passagem do tempo, converte-se na própria realidade histórica da nação. Ironicamente, o mito funciona como portador de verdades profundas (ou falsidades?) em sentido histórico, ainda que a sua funcionalidade como mito dependa de privá-lo da sua contingência histórica.

É contra esta mitologia e a mistificação do Estado Novo e a sua visão imperialista que controlam o povo português e imobilizam a nação, assim como da quase impossibilidade da construção de uma realidade alternativa ou diferenciada fora do discurso de O.S., que se insurge Hortense, a protagonista de Passagem. Não permitida a sua entrada na linguagem por a linguagem ser falicamente autorizada ou uma prerrogativa masculina, "Hortense contemplates suicide in terms of an act of non self-recognition in a glass pane" (OWEN, 2000, p. 43), a "[p]erder, de repente, a sua vida, e não reconhecer o seu rosto reflectido na vidraça. Vaguear pela casa, interrogando-se cada coisa, e nenhum objecto ter mais relação consigo" (9). "Her survival can only proceed from inventing a new imagined unity out of the fragments" (OWEN, 2000, p. 43). "O real tinha-se tornado um jogo de transparências, ela era uma sombra num vidro, uma sombra passando, atravessando as coisas sem tocá-las, um corpo de vidro caindo de uma janela alta, um corpo rebentando em estilhaços de granada" (23). A sua essência fragmentada e o seu corpo estilhaçado correlacionam-se perfeitamente com a fragmentação de Passagem, um texto produzido por múltiplas vozes e vivido por muitas pessoas que a escritora, como ela salienta na epígrafe do romance, devolve "apenas um pouco mais organizado debaixo desta capa de papel, a quem o reconheça como coisa sua" (5).

Mas que caminho tem que seguir Hortense para encontrar a sua unidade e a sua voz? Como poderão ela e outras mulheres, incluindo as próprias escritoras pósrevolucionárias, reconfigurar e reescrever o seu papel tradicional ao serviço do discurso fascista/colonialista, do patriarcado e da pátria para assim poderem desafiar a lei paterna que autoriza a linguagem e deixarem de ser unicamente "the traditionally silent wombs of history" (FERREIRA, 1997, p. 220), como observa Ana Paula Ferreira. No caso de Hortense, o início da sua fuga à representação hegemónica ocorre quando morre o seu filho Pedro em um combate na guerra colonial. Conforme Ana Paula Ferreira, the death of her son crystallizes the character's longsedimented suspicion of how language mediates and structures the fictitious structure of the law [...], more precisely 'the right words of Oliveira Salazars's law. Empty signifiers, pure simulacra of the world without a Real referent' (FERREIRA, 1997, p. 229).

Significantes que têm características análogas às do mito. Se, por um lado, a linguagem, nomeadamente a de O.S., significa a morte do sujeito, por outro lado, também será através da linguagem que Hortense terá a possibilidade de construir uma realidade alternativa. E decide-se por seguir esta opção após a morte do filho. Hortense vai entrar em uma luta desigual contra as forças de O.S., visto que estas forças despojam as palavras do seu significado e quando, finalmente, as palavras se transformam de novo em coisas em vez de elas terem uma correspondência real com as coisas elas são uma falsificação e uma sombra das coisas, um simulacro, portanto. No mundo de O.S. o simulacro é mais real que a própria realidade; e é quase impossível escapar dele porque ele é mais importante que o próprio objecto. $\mathrm{O}$ importante em Paisagem, por exemplo, não é a realidade do mar mas todas as implicações simbólicas do mar, o seu simulacro. Ao reflectir sobre a linguagem e a realidade de O.S. na sua tentativa de escape ao simulacro do real, Hortense dá-se conta de que

[o] que existia era apenas uma ridícula contratação do mundo, um enorme deserto de palavras falsas, e então ela começou a lutar contra as palavras falsas e deixou correr a sua voz dizer qualquer coisa, não importa o quê, apenas quebrar o silêncio, levantar uma voz frágil, absurda, confusa, mas uma voz, contra o mundo informe do caos e do silêncio, a voz como revolta, não poderiam calar a sua voz (15-16).

Contudo, a sua tentativa de escape causa uma reacção forte e imediata das forças do país de sombras, de simulacros. As palavras falsas de O.S. fazem um cerco apertado às palavras verdadeiras, imobilizam os corpos das pessoas, transformam-se em uma boca gigantesca que devora todas as coisas ao seu redor ou convertemse em "línguas, mandíbulas, dentes batendo, enquanto fragmentos de palavras eram repetidos, a uma velocidade vertiginosa" (17) com a intenção de atormentar as pessoas e causar tensão e angústia. Para atingir a sua meta, ou seja, recuperar a sua voz Hortense necessita encontrar o centro do seu mundo porque sem ele, O.S. metaforizado em mar

calava sempre a sua voz para que só a voz dele existisse, a sua voz imensa, omnipresente, que trazia em si todas as vozes, mesmo as impossíveis, [...] porque para o mar não havia distância, estava em todos os lugares unindo tudo, [...] parava o tempo, aquietava as coisas. Era uma voz que paralisava e entorpecia, e 
quem ficasse escutando acabaria por ceder ao encantamento, desceria a correr as escadas do mar e ficaria mil anos dormindo no fundo, o corpo transformado em pedra (32).

Hortense, na sua tentativa de criar um espaço onde a lei de O.S. não tem poder algum e que lhe permite a reconstituição da sua subjectividade, vale-se da memória de um passado feliz tanto em família como com o esposo Horácio já falecido, assim como de uma posição política sempre desafiante e anti-mimética, sobretudo no que concerne os desenhos de escola primária e pinturas posteriores sempre guiados por uma imaginação livre. Nos seus desenhos e pinturas, ela potencializa, através de uma linguagem visual inovadora, a transformação da própria realidade onde a "terra não só tal como é, mas tal como a transformo [Hortense]" (77). A sua arte, que era causa de grande satisfação pessoal para ela, desafia incessantemente a lei do pai (O.S.), a qual se fundamenta em uma posição mimética na sua relação com a realidade. Afora a recuperação dos fragmentos da sua memória, a protagonista começa também a aceitar o facto de que não se pode fechar em si, que o mundo existe para além dela. Não é só uma questão de auto-reconhecimento ou de reconstituição da subjectividade fragmentada, é também redescobrir-se em e estabelecer laços de solidariedade com os outros, especialmente as mulheres como quem conviveu ou ainda convive: Casimira, a criada; Elisa, a irmã; Clara, a nora; e a avó. A solidariedade e a relação intersubjectiva com outras mulheres, para dizer a verdade, são armas que representam uma forte ameaça ao poder de O.S., a causa directa da sua subjectividade fragmentada. Adicionalmente, Hortense precisa livrar-se de um mar metaforicamente relacionado com o poder fascista/ imperialista, um mar deserto sem paisagem, que também é a causa do seu corpo de vidro estilhaçado e que a priva de sonhar, de imaginar. "[D] esaparecera a sua ligação com a terra, havia uma falta de fixação no solo, uma ausência de raiz" (24) e ela tem que tornar ao "reino de que ela possuíra sempre a chave" (61) e "[o]nde a decomposição e a morte eram só mudança, superação da forma, nascimento adiado, prometido" (62) para colmatar uma ruptura com o espaço ausente do qual se sente desligada, a terra, e reconstituir, assim, a sua unidade fragmentada.

Todas as mulheres, e Hortense não é uma excepção à regra, estão sujeitas a restrições normativas relacionadas com a casa e o corpo (OWEN, 2000, p. 46) por parte do discurso hegemónico, cujo líder O.S. é dono exclusivo da única verdade e da única linguagem. Segundo Owen, "[t]he choice between complicity and resistance is written into the very fabric of their daily lives" (46) porque "cada coisa tinha a sua hora, a oração, os remédios, a leitura, a rádio, o jornal, no meio da morte sentia-se útil, devotada, esquecida de si mesma, uma mulher perfeita, um exemplo" (85). Para os que querem desestabilizar o sistema, ou seja, os que desejam ter boca para criar a sua realidade em um país de um povo sem boca, a fuga à condição de reflexo ou simulacro imposta neles por O.S. é essencialmente uma impossibilidade. Além do mais, correm o risco de que O.S. lhes corte a voz. Como ele afirma, "[o] meu reino é um reino de espelhos, um jogo de reflexos" (95) e esta é a realidade do povo. Não existe um povo real na nação; só existe um simulacro ou imagem do povo. Também a realidade do país é pura falsificação. É a imagem que o espelho devolve, portanto, é reflexo, um simulacro. É o jogo da criação do mundo através de palavras como frases feitas; de versões de factos em vez de factos; de mitos em vez do real histórico; de opressão, de guerra colonial, de sacrifícios, de partidas e mais partidas em vez do mar. Tudo é um jogo de reflexos; não há correspondência entre as palavras e uma realidade profunda no mundo de O.S. Quem controla o povo são as aparências, os reflexos e o jogo de espelhos do reino de O.S.

É fácil apontar um dedo acusador a O.S. e culpálo de todos os problemas existentes na nação, incluindo a paralisação da sociedade, a repressão e opressão, as guerras coloniais, as vozes silenciadas, e a política colonialista/imperialista. No entanto, uma legenda no pedestal de pedra de uma estátua dedicada a "um soldado morto, caindo por terra varado por mil balas" (55) onde se lê "A O.S., as mães agradecidas" (55) alude a uma possível cumplicidade de parte de muitas pessoas na sua própria sujeição à situação imobilizadora e opressiva do país e ao abuso de poder por parte de O.S. Embora uma das condições requeridas para o êxito do poder simbólico é que "those subjected to it believe in the legitimacy of power and the legitimacy of those who wield it" (23), o facto é que muitos portugueses considerados vítimas da política salazarista colaboraram de forma activa na sua própria vitimização, incluindo muitas mulheres que pactuaram, segundo o texto, contra os filhos vis-à-vis as guerras coloniais, (i.e., as mães agradecidas), porque elas nunca disseram aos filhos que não fossem para a guerra. Estas mulheres nunca levantaram as suas vozes contra a insensatez das guerras coloniais. Como sublinha o texto,

é mais fácil ficar sentada a tricotar do que pensar alguma vez nessas coisas, [...] porque se alguma vez uma mulher pensasse poderia recusar ter um filho e nesse caso não teria pretexto algum para tricotar e como seria possível a uma mulher viver sem tricotar (55).

Esta alusão a mulheres sentadas a tricotar parece ser um caso absurdo de falta de compaixão de umas Penélopes portuguesas aparentemente culpadas da sua vitimização e também da dos filhos que ao ter que escolher entre preservar a sagrada instituição do tricô 
ou mandar os filhos para a guerra, optam pela primeira opção. Com esta sua escolha mantém-se viva a suposta razão real e simbólica da instituição do tricô: a espera pelo regresso de uma pessoa amada - filho ou até marido mesmo que morto -, uma situação análoga à de Penélope à espera de Ulisses em Ítaca. Outra possível leitura deste fragmento sobre o tricô é que é O.S. que cria as condições para as mães portuguesas pensarem que estão a sacrificar-se em prol da nação, dado que os legítimos interesses desta estão em perigo. Neste caso, não são as mães que são cúmplices na sua vitimização mas sim os líderes políticos que, mediante uma retórica fascista fundamentada na regeneração e em uma visão mística da nação que serve unicamente os interesses dos detentores do poder e não da nação, criam as condições ideais para as mães aceitarem colaborar na sua vitimização. Como se afirma em Paisagem, é "dentro de nós que está a tentação do caminho mais fácil, a voz da resignação, do desespero e da morte, e essa também é a voz de O.S.” (146). Na realidade, é a voz de O.S. que faz as decisões pelo povo português, incluindo as das mães agradecidas.

Finalmente, o sonho sempre desejado e adiado da derrocada final do império de O.S. e da subversão da casa/ prisão da linguagem privada de seu contexto histórico que tinha prisioneiro todo o povo português convertem-se em realidade com a revolução, ou melhor, com a festa partilhada de "um poder que cai e outro se levanta" (124), como diz o texto. Há um episódio de Paisagem que antecipa ou prefigura a revolução desejada e que serve de modelo para todo o acto revolucionário. Refiro-me especificamente à tentativa de suicídio por parte de Clara. Ela, grávida de Pedro, o filho de Hortense morto na guerra, decide ingerir valium por não poder suportar mais a situação política do país e doravante, depois da morte de Pedro, estar obrigada a enfrentála sozinha. Hortense, quando se dá conta da tentativa de suicídio, faz tudo ao seu alcance para salvar a vida da nora, incluindo exortá-la, através de uma conversa imaginária que tem com ela no hospital, a lutar contra o poder de O.S., a pessoa responsável pela tentativa de suicídio. Na sua exortação, Hortense diz:

cada minuto te afasta um pouco mais, sinto avançando, vais caindo para o fundo de um mar e cada vez é mais espessa a cortina de água , [...] para descer só precisas de deixar-te cair, [...] mas para vir à superfície terias de fazer um esforço enorme, não cedas, grito, arrancamoste do fundo do mar e trazemos-te connosco para terra, mas por favor escolhe voltar, porque não podemos fazer nada contra a tua vontade (146).

Como observa Hortense, é fácil para Clara deixarse morrer afogada no mar, um mar representando metaforicamente O.S e que é o espaço do próprio reino de O.S., porque assim acaba de vez a luta infindável com o seu algoz. Por conseguinte, ela implora que Clara faça um esforço enorme para vir à superfície. É a partir deste momento que a voz de Hortense se converte em voz plural porque ela finalmente chega à conclusão que só vozes solidárias podem salvar Clara ou qualquer outro indivíduo do inevitável: a morte. No entanto, é imprescindível, para o êxito destas vozes, a cooperação de Clara. Ela também tem que se solidarizar com a luta dos outros contra O.S. ou o mar e se consciencializar de que "é também dentro de nós que está a tentação do caminho mais fácil" (146) para se salvar das águas do mar. A questão da solidariedade para derrotar o inimigo torna-se ainda mais óbvia quando Hortense, imediatamente depois, enumera tudo e todos aqueles que contribuíram para a salvação de Clara e conclui dizendo: "o coração da cidade pulsando, somos um só corpo solidário" (146).

É este "um só corpo solidário" (146) que finalmente leva a cabo o acto revolucionário denominado historicamente como a Revolução de 25 de Abril. O acto em si dura um só instante e nem todos participam desse instante. Embora haja umas quantas referências textuais aos eventos do 25 de Abril, o acto revolucionário em si é denominado a festa partilhada, escolha que priva o evento de sua referência histórica mas que melhor traduz a emoção e a pulsação política e ideológica do evento, ou seja, o povo unido como se fosse um só corpo solidário derrubando simbolicamente O.S. do seu trono e o império com ele porque sem O.S. não há império. Mesmo que a festa partilhada dure apenas um só instante e que já se observe, quase de imediato, a sombra de O.S. com a sua lei e a sua retórica paralisante, o facto é que a luta partilhada que nunca tem fim "é um caminho que segue para a frente, e se nos disserem que o movimento é aparente, nós provaremos que não é, andando" (125). $\mathrm{O}$ andar, neste caso, é uma forma de resistir a possíveis injunções futuras para representar outras ficções políticas decretadas como se fossem leis por outro O.S. Aparecerá de certeza outro O.S. no futuro e o corpo solidário tem de estar preparado para essa eventualidade. Outro factor importante a considerar é o facto de que O.S. não tem o poder em si; ele só tem o poder que o povo lhe dá. Quando o povo se dá conta de que possui o poder, O.S. cai do trono.

A guisa de conclusão deste ensaio devemos sublinhar que Hortense, cujo signo é a terra, depois da morte/ destruição de O.S., símbolo do mar, e, por extensão, do império e tudo o que é associado a ele, pode por fim pisar a terra abandonada e incógnita e descobri-la de novo. A sua maior felicidade é caminhar pelo reino vegetal de que ela possui a chave, reino que dá unidade ao seu corpo fragmentado, de estilhaços de vidro. Na realidade, a estrutura de Paisagem fundamenta-se em uma oposição binária de mar e terra. Há uma luta constante entre estas 
duas forças. O.S. puxa todo o povo para o mar, o seu reino ou domínio, por excelência, onde ele sufoca a voz do povo. Como é o princípio e o fim e dado que todos os lugares estão nele e por isso mais desertos, ninguém pode escapar do seu reino ou da sua vigilância. $\mathrm{O}$ seu controle sobre o povo é total e a sua tirania não tem limites. Ele cria um reino de afogados, sem revolta, tão condicionados e manipulados pela retórica fascista/imperialista que eles se convertem em cúmplices da sua própria vitimização. Nas mãos de O.S. a linguagem converte-se em um instrumento eficaz na construção do seu imaginário. Ele usa-a como se ela fosse a origem da história e não uma consequência das forças da história. Devido ao seu uso específico da linguagem para construir a história, a nação sé pode viver de ficções e de fantasmas que levam eventualmente à ruína do império e da própria nação. O.S. não está interessado em uma representação real da história da nação mas sim em uma representação do que ele imagina que a nação é. O mundo de O.S. convertese em uma espécie de jogo de espelhos, de reflexos, de simulacros e de transparências totalmente despojados de um contexto histórico específico. Por isso é que O.S. recorre aos mitos, símbolos, cerimónias, exposições, metáforas e rituais para construir o imaginário da nação/ império. Só Hortense e algumas mulheres, assim como Gil e Horácio, têm consciência das falsificações e manipulações de O.S. e do seu uso da linguagem, despida de toda a contingência histórica, para controlar, silenciar e manipular o povo e paralisar o país. Apesar do seu poder supostamente ilimitado, O.S. cai do trono e a derrocada do império é inevitável. Com esta derrocada, Hortense pode, por fim, "[v]oltar as costas ao mar [deserto] e encontrar a terra" (61), um espaço onde ela poderá metaforicamente nadar ou navegar no mar de vegetação, símbolo de vida e não de morte como o mar, e intersectar com os outros em um só corpo solidário e com a própria paisagem, a palavra inicial do título da obra, doravante uma paisagem despida de mitos e sem mar ao fundo, um mar sempre associado a partidas, morte, silêncio, repressão, império, colonização, missão civilizadora e imobilização do país.

\section{Referências}

BARTHES, Roland. Mythologies. New York: Hill and Wang, 1976.

AGÊNCIA GERAL DAS COLÓNIAS. Boletim Geral das Colónias, Lisboa, v. 1, n. 2, p. 230, 1925.
AGÊNCIA GERAL DAS COLÓNIAS. Boletim Geral das Colónias, Lisboa, v. 17, n. 167, p. 1-464, 1949.

BORDIEU, Pierre. Language and symbolic power. Cambridge: Harvard University Press, 1991.

DIAS, Maria Heloísa Martins. A presença de elementos míticos na narrativa de Teolinda Gersão. Disponível em: <http:// hottopos.com/notand7/heloisa.htm>. Acesso em: 1 ago. 2010. (p. 1-11).

FERREIRA, Ana Paula. Reengendering History: Women's Fictions of the Portuguese Revolution. In: KAUFMAN, Helena. KLOBUCKA, Anna. After the Revolution: twenty years of portuguese literature, 1974-1994. Lewisburgh: Bucknell University Press, 1997.

GERSÃO, Teolinda. Paisagem com mulher e mar ao fundo. Lisboa: O Jornal, 1982.

GERSÃO, Teolinda. A árvore das palavras. Lisboa: Publicações Dom Quixote, 1997.

GOMES, Sérgio Alexandre da Rocha. As identidades nacionais nos regimes ditatoriais: o caso da romanità na Itália fascista e $\mathrm{o}$ reportuguesamento salazarista. Revista da Faculdade de Letras: ciências e técnicas do património, Porto, v. 5-6, p. 189-224, 2006-2007.

KAUFMAN, Helena; KLOBUCKA, Anna. After the Revolution: twenty years of portuguese literature, 1974-1994. Lewisburgh: Bucknell University Press, 1997.

MENESES, Filipe Ribeiro de. Salazar. Lisboa: Publicações Dom Quixote, 2009.

ORNELAS, José. Paisagem com mulher e mar ao fundo: a positividade e a afirmação da diferença. In: REMÉDIOS, Maria Luíza Ritzel (Org.). O despertar de Eva: gênero e identidade na ficção de língua portuguesa. Porto Alegre: EDIPUCRS, 2000. p. $145-164$.

OWEN, Hillary. Portuguese Women's Writing 1972 to 1986: reincarnations of a revolution. Lewinston: The Edwin Mellen Press, 2000.

PESSOA, Fernando. Mensagem. Lisboa: Ática, 1967.

RIBEIRO, Margarida Calafate; FERREIRA, Ana Paula. Fantasmas e fantasias imperiais no imaginário português contemporâneo. Lisboa: Campo das Letras, 2003.

SALAZAR, António de Oliveira. Discurso de Sua Excelência o Presidente do Conselho. Boletim Geral das Colónias, Lisboa, v. 17, n. 167 , p. $24-28,1949$.

SARAMAGO, José. O ano da morte de Ricardo Reis. Lisboa: Caminho, 1985.

Recebido: 22 de abril de 2014

Aprovado: 15 de junho de 2014

Contato: ornelas@spanport.umass.edu 